\title{
Esensi Ritual Melukat sebagai Daya Tarik Wisata Spiritual
}

\author{
Nyoman Mahardika \\ Magister ILKOM IHDN Denpasar \\ Angga Angkasa (Mahasiswa STP Bali)
}

\begin{abstract}
In the midst of the rapid interest of the Hindu community in Bali to perform the melukat ritual, an interesting phenomenon occurred in the Penglukatan Village of Pekraman Sebatu Village in Tegallalang Gianyar, Bali, where everyone can see for themselves the changes in water that occur as a sign of a real cleaning process. This 'peculiarity' resulted in word of mouth propaganda phenomenon, making this place of knowledge suddenly famous. Not only the local community, foreign guests are also attracted by the power of mouth from a phenomenon that was first discovered accidentally by a foreign tourist. Thousands of foreign tourists join in every month. This study intends to provide different perspectives that understand and carry out melukat essence, related to self-empowerment efforts to improve the quality of people's lives, because basically every ritual is only a tool for self-empowerment, not purpose. Also reviewing this phenomenon from a tourism perspective, given the positive response from the 'market'. The novelty that is to be offered is a form of spiritual tourism that does not sell sensations, but tours that promote self-empowerment as a result of the declaration of local wisdom that is able to provide an inner experience that is recharge their spiritual spirituality. As well as being able to be communicated logically, scientifically and interestingly.
\end{abstract}

Keywords: Ritual, Attractions, Tourism

\section{Pendahuluan}

Belakangan ini, fenomena yang cukup menonjol dikalangan umat Hindu, di Bali khususnya, adalah meningkatnya minat untukmenjalankan Tirtayatra atau melakukan perjalanan ke tempat-tempat suci untuk melakukan ritual persembahyangan, bermeditasi, mengambil tirta (air suci) dan sering juga dirangkai dengan ritual melukat.

Dalam Sarasamuccaya 279, diuraikan keutamaan Tirtayatra sebagai berikut :

"sada daridrairapi hi cakyam praptum naradhipa, tirthabhigamanam punyam yajnerapi wicisyate”. Artinya :Keutamaan tirtayatra sungguh suci, bahkan lebih suci daripada Yajnya dan mampu dilakukan oleh mereka yang miskin sekalipun. Dewasa ini dan di masa-masa yang akan mendatang, akan semakin banyak umat melakukan tirtayatra yang dirasakan kenikmatannya untuk mengurangi beban hidup keseharian yang penuh dengan tantangan (IB Dharmika, 2017 : 110). 
Apakah motif untuk ber-tirtayatra termasuk di dalamnya ritual melukat, semata untuk merasakan kenikmatannya, dalam pengertian sebatas memanfaatkan sensasinya sebagai sarana untuk refreshing, sehingga hidup dapat terasa lebih ringan?Apakah desakan keinginan tersebut yang mengakibatkan Penglukatan di Sebatu Tegallalang Gianyar selalu dibanjiri pengunjung ?Bagaimana kalau perspektif terhadap ritual ini diubah, dengan lebih kreatif melihatnya sebagai sebuah Sadhana (disiplin spiritual) untuk pemberdayaan diri umat ? Dengan demikian, bukan hanya hidup terasa (seakan) lebih mudah, tetapi hidup akan disadari dan dijalani sebagai sebuah kemuliaan dan berkah.

Ternyata melukat bukan hanya diminati oleh masyarakat Hindu lokal, tamu manca negara juga menaruh minat yang cukup besar terhadap kegiatan ini. Hal ini dapat dilihat dari jumlah kunjungan wisatawan asing ke objek penglukatan di Desa Pekraman Sebatu sebagaimana table berikut :

Daftar Jumlah Kunjungan Wisatawan Asing ke Penglukatan Pura Dalem Pingit / Pura Kusti Desa Pekraman Sebatu Kecamatan Tegallalang Gianyar Bali sejak dikenakan punia Desember 2017

\begin{tabular}{|c|rr|rr|}
\hline $\begin{array}{l}\mathrm{N} \\
\mathrm{o}\end{array}$ & Bulan / Tahun & $\begin{array}{r}\text { Jumlah wisatawan asing } \\
\text { melukat }\end{array}$ \\
\hline 1 & & 568 orang \\
\hline 2 & Desember 2017 & 1.102 & orang \\
\hline 3 & Januari & 2018 & 960 & orang \\
\hline 4 & Februari 2018 & 1.360 & orang \\
\hline 5 & Maret & 2018 & 1.490 & orang \\
\hline 6 & April & 2018 & 1.600 & orang \\
\hline
\end{tabular}

Sumber : Desa Pakraman Sebatu Tegalalang Gianyar

Dengan adanya minat wisatawan asing yang cukup besar untuk ikut melukat, berarti potensi untuk menjadikannya wisata spiritual cukup besar.

Dari pengalaman yang sudah sudah, berkembangnya pariwisata meningkatkan kesadaran material dan menciptakan ketergantungan kepada pariwisata sebagai industri, yang berakibat matinya kreativitas masyarakat dan membuat kita lupa akan kekuatan kita (Anand Krishna, Majalah Craddha, Edisi 82:34). Bagaimana menjawab tantangan tersebut dalam pengembangan destinasi wisata melukat ini?

\section{Pembahasan}

Pada tahun 2006, seorang tamu yang kebetulan berada di Desa Sebatu, minta diantarkan pemandu wisatanya, I Wayan Yudi asal Banjar Sebatu yang berdomisili di Kuta,ke tempat permandian untuk mandi. Karena tidak ada permandian umum, maka tamu tersebut diajak ke lokasi tempat penglukatan sekarang (saat itu masih berupa sumber air biasa yang dimanfaatkan masyarakat untuk keperluan upacara dan kebutuhan sehari-hari). Pada saat pertama kali mengguyurkan badannya di bawah pancuran besar, dia keheranan menyaksikan bahwa air yang sudah melewati badannya berubah menjadi putih seperti air cucian beras. Keanehan itu berlangsung beberapa lama sampai akhirnya bening kembali. Setelah kejadian tersebut, dia merasakan badannya menjadi sangat segar. Keanehan dan testimoni sensasi mandi tersebut pun dalam waktu singkat menyebar dari mulut ke mulut. Semakin banyak yang membuktikan keanehan tersebut dan merasakan sendiri kebugaran yang didapat setelah mengguyurkan seluruh badan di sana, semakin 
tersebar berita penemuan tempat penglukatan baru di Sebatu tersebut ke seluruh Bali, bahkan di kalangan wisatawan asing pun terjadi hal yang sama, fenomena tersebut menyebar dari mulut ke mulut dengan sangat cepat.

Merespon fenomena tersebut, pimpinan Desa Pekraman dan masyarakat Sebatu akhirnya pada tanggal 14 Nopember 2007 melaksanakan upacara keagamaan "Mendak Tirta" menandai dibukanya tempat pengelukatan yang menurut Petunjuk Ida Batari Sang Hyang Dedari di Desa Pekraman Telepud dan intuisi Jero Gede Pura Batur, merupakan tempat pemandian Ida Betara Pura Dalem Pingit dan Pura Kusti Sebatu. Sejak itu, tempat tersebut diberi nama Pengelukatan Pura Dalem Pingit dan Pura Kusti. Yangberstana di sana dan diyakini memberikan berkah dalam setiap pengelukatan adalah Ida Batari Uma dan Ida Dewi Gangga. Kawigunan atau manfaat utama penglukatan ini yaitu melebur segala 'mala' (kekotoran diri, penyakit, termasuk akibat black magic) dan 'Nunas Sentana' (Memohon diberkahi keturunan). Sedangkan yang tidak diperkenankan untuk ikut melukat (pantangan) adalah anak yang belum mengalami tanggal gigi (dalam bahasa Bali : Ketus gigi) dan wanita yang sedang menstruasi.

Sampai sekarang, sudah tidak terhitung banyaknya umat yang terbukti mendapatkan berkahtersebut. Hal ini ditandai dengan begitu banyak umat yang datang kembali untuk melakukan persembahyangan sebagai ucapan syukur (sebagian menganggapnya sebagai pembayaran kaul) karena permohonannya sudah terkabulkan atau telah berhasil sembuh. Walau demikian, pihak Pengempon (Pengelola) tidak pernah menjadikan hal ini sebagai propaganda kepada khalayak, umat dan wisatawan, apalagi sebagai jaminan kepastian keberhasilan dalam ritual melukat di sana.

Informan juga memberikan penjelasan tentang sarana pengelukatan yang diperlukan. Bagi masing-masing keluarga atau rombongan yang datang untuk pertama kali melukat, disarankan untuk membawa satu pejati dengan canang dan kelengkapan persembahyangan. Sedangkan pada saat melukat, masing-masing mempersembahkan kwangen, berisi bunga tunjung biru dan bunga jempiring, dengan 11 kepeng uang bolong. Seluruh kelengkapan tersebut, saat ini sudah ada yang menyediakan di sana.

Sebelum melakukan pengelukatan, Pejati atau banten dihaturkan di depan pelinggih Ida Betari Uma dan Ida Dewi Gangga, dilanjutkan dengan melakukan persembahyangan untuk memohon berkah apa yang menjadi tujuan dalam melukat. Setelah berganti busana (tetap memakai kain dan bagi kaum perempuan memakai atasan yang sopan), prosesi melukat dilakukan dengan terlebih dahulu berdoa di depan 'gerojogan' (pancuran dengan debit yang sangat besar) dengan posisi tangan Anjali mudra di dada sambil memegang kwangen, kemudian mengambil posisi dibawah guyuran air. Seberapa lama proses melukat dan bagian tubuh mana yang lebih sering diguyurkan di bawah 'gerojogan' air, mengikuti intuisi masing-masing. Selesai melukat, sebelum melakukan pergantian busana, dalam kondisi seluruh tubuh masih basah, kembali melakukan persembahyangan dengan sarana Canang, bunga dan dupa untuk mengucapkan syukur atas pelaksanaan melukat yang berlangsung lancar dan khidmat. Untuk peserta melukat atau wisatawan yang tidak beragama Hindu, disarankan untuk tetap mengikuti urutan dan sarana sebagaimana sudah dijelaskan, agar mendapatkan 
hasil yang maksimal. Sedangkan tata cara bersembahyang atau cara memanjatkan doa, disesuaikan dengan keyakinan masing-masing.

Sensasi melukat memang dapat memberikan efek segar bagi badan dan pikiran. Badan dan pikiran menjadi lebih fresh dalam menghadapi tanggungjawab kehidupan berikutnya. Ditambah lagi adanya keyakinan akan turunnya berkah lewat ritual ini, maka efek penyembuhan baik secara fisik dan psikis sudah bekerja, disadari atau tidak. Sebagaimana ritual -ritual lainnya dalam kegiatan keagamaan, ritual melukat sebagaimana dijelaskan di atas adalah bentuk pelaksanaan ritual yang dilakukan sebagian besar penganut agama Hindu yang dikategorikan sebagai tipologi manusia Hindu eksoteris. Masih mengandalkan ritual sebagai jalannya berbakti kepada Sang Pencipta.

Ada tipologi yang lain yang dikatakan lebih maju dalam spiritualitas atau kerohanian, yaitu seperti para Yogi, atau Sufi dalam tradisi Muslim, Santo dalam tradisi Katolik, atau Biksu dalam tradisi Buddha, disebut tipologi Isoteris. Kaum isoteris akan melihat spirit dari setiap ritual, spirit ritual menjadi kata spiritual. Mereka melakoni spiritual dalam seluruh gerak kehidupannya. Mereka kelihatannya tidak memerlukan ritual melukat untuk pembersihan diri, tapi sesungguhnya laku mereka setiap saat adalah pembersihan diri dengan doa atau mantra dan sadhana spiritual lainnya dengan disiplin diri. Mereka tampak tidak lagi memohon berkah tertentu, karena hidup bagi mereka adalah berkah.

Pada jaman Postmodern ini, menghadapi segala perubahan bersama generasi baru $\mathrm{Y}$ dan Z, dan juga untuk dapat mengkomunikasikan fenomena melukat ini kepada wisatawan asing, harus ada penjelasan logis, termasuk dalam urusan keyakinan. Bagaimana sesungguhnya esensi melukat yang dapat diterima secara rasionalitas dan antroposentrisme (yang memandang manusia sebagai pusat dari sistem alam semesta).

Terkait dengan fenomena bahwa manusia adalah subyek, tokoh fenomenologi Peter Berger melihat setiap tindakan manusia adalah produk dari proses internalisasi dan eksternalisasi, serta cenderung konstruksiotik. Setiap tindakan manusia dilakukan secara dialektis di dalam dan bagi dirinya sendiri, serta dalam dirinya dengan kondisi masyarakat sekitarnya. Manusia adalah subyek yang kritis dan problematik, artinya menyertakan pengetahuan yang dimiliki oleh subyek (Engkus, 2009 :20). Membahas esensi melukat sebagai pengetahuan akan mampu memberikan perspektif baru yang memberdaya dan membawa manfaat besar bagi diterimanya melukat sebagai kegiatan dalam membangun kesehatan dan kebahagiaan secara holistik (menyeluruh).

Lepas dari segala bentuk sensasi-sensasinya, esensi ritual melukat dapat dirasionalisasisecara kritis sebagai kegiatan pemberdayaan diri yang sangat efektif.

Sebelumnya, apabila dicermati lebih mendalam dan didekodifikasi, Sloka Sarasamuscaya 277 yang berbunyi : "akrodhanacca rajendra satya cilo drdhawratah, atmopamacca bhutesu sa tirthaphalamacnute ", yang artinya : "Mereka yang tidak dirasuki oleh amarah dan kebencian, mereka yang mencintai kebenaran, tetap teguh dalam pengendalian indrawi, mengasihi segala makhluk seperti mengasihi diri sendiri; orang yang melakukan hal tersebut akan memperoleh kebahagiaan yang sama dengan orang yang tekun bertirtayatra", 
maka bertirtayatra termasuk melukat bukan hanya dianggap memiliki dampak yang sama dengan pemberdayaan diri, melainkan melukat itu sendiri identik dengan pemberdayaan diri.

Pemberdayaan diri melalui ritual melukat bersifat holistik atau menyeluruh menyangkut pemberdayaan kelima lapisan kesadaran diri manusia sebagaimana dijelaskan dalam Kitab Hindu Traitiriya Upanishad seperti ilustrasi gambar berikut :

\section{LIMA LAPISAN KESADARAN MENURUT TAITTIRIYA UPANISHAD}

1. Annamayakosha (Badan fisik)

2. Pranamayakosha (Energi/nafas)

3. Manomayakosha (Mind/Mental-emotional)

\section{1.} 2. 3. 4. 5.

4. Vjnanamayakosha (Buddhi/Intuisi)

5. Anandamayakosha (Kesadaran Murni)

(Mahardika, Komunikasi Meditatif dalam Konsepsi Hindu, Prosiding Seminar Nasional Komunikasi FDD IHDN Denpasar, 22 Mei 2018)

1. Pemberdayaan dan pembersihan Annamayakosha atau badan fisik manusia. Di dalam lapisan ini juga terdapat panca indra yang bertugas sebagai alat sensor sebagai penghubung antara badan dengan dunia luar. Prosesi melukat dapat melibatkan dan merupakan pembersihan seluruh indra;

2. Pemberdayaan Pranamayakosha atau lapisanEnergi kehidupan. Sensasi perubahan energi tubuh yang kontak langsung dengan energi semesta melalui air yang berkualitas terbaik, sangat terasa menyegarkan. Implikasinya adalah bangkitnya kelegaan dan semangat. Bukan semangat biasa seperti halnya gairah yang dilandasi nafsu, melainkan semangat yang didasari atas ketenangan dan kedamaian. Dengan sikap membuka diri, tanpa mencari-cari atau berharap sesuatu, Energi alam semesta yang bersifat murni akan memenuhi setiap sel badan, menghasilkan kebugaran yang prima.

3. Pemberdayaan Manomayakosha (atau lapisan Manas, Mind atau gugusan pikiran yang terdiri dari pikiran rasional dan pikiran emosional) terjadi pada saat membuka diri dan hanya mengamati proses melakukan pengguyuran air di kepala. Segala bentuk ego dan emosi negatif yang bercokol pada lapisan ini akan tidak eksis. Pada saat itu, pikiran kolektif Semesta, yang terhubung dengan segala kebijaksanaan alam mengambil alihkesadaran pikiran. Inilah 
yang menghasilkan transformasi pikiran menjadi lapisan kebijaksanaan atau intuisi.

4. Lapisan Vjnanamayakosha yang juga disebut dengan Buddhi, Inteligensia, Intuisi, Viveka atau Wisdom, dalam prosesi ini langsung selaras dengan irama inteligensia sumbernya yaitu alam semesta. Lapisan bathin atau nurani yang terhubung dengan semesta menghasilkan sensasi ketenangan dan rasa damai yang sangat luar biasa. Semua ini 'tidak masuk akal' karena memang entitas ini seluruhnya beyond mind, di luar pikiran, dimana ego dan semua fluktuasi emosi tidak lagi eksis.

5. Rasa haru dan bahagia yang tidak terjelaskan adalah sensasi yang mengindikasikan lapisan Anandamayakosha atau Kesadaran Murni (Bliss atau kebahagiaan sejati) tempat Sang jatidiri bersemayam, tersentuh. Prosesi bersembahyang atau menghubungkan diri dengan Sang Pencipta, setelah semua lapisan terkondisikan secara baik, memberikan hasil yang tidak mampu dilogikakan. Terhubungnya Dia Yang Bersemayam di dalam diri (Atman) penguasa Buana alit dengan Sang Paramatma Penguasa Buana Agung, menghasilkan kebahagiaan sejati yang tidak bisa dijelaskan, kecuali dirasakan dengan mengalaminya.

Mengenali, memahami dan melakoni esensi melukat sambil melakukan prosesi melukatdengan penuh kesadaran, adalah langkah yang tidak mudah. Langkahlangkah ini merupakan proses bertumbuh dari eksoteris ke isoteris. Proses melukat dengan meditatifhanya akan berhasil apabila dilaksanakan dengan cara:

Satu, penuh kesadaran diri secara terus menerus (orientasi kesadaran ke dalam diri atau tidak melakukannya secara mekanis ). Untuk dapat mengembangkan kemampuan melakukan melukat dengan meditatif (berkesadaran secara terus menerus) ini, diperlukan latihan-latihan tambahan sebelumnya, yaitu membiasakan diri untuk bermeditasi atau melakukan latihan duduk hening mengamati diri sendiri, mulai dari mengamati badan, nafas, pikiran, segala kebijaksanaan dan rasa bahagia yang muncul, tanpa melakukan penilaian atau menghakimi.

Kedua, sikap kepasrahan yang mendalam ketika membuka diri terhadap sentuhan alam yang diterima (orientasi ke alam semesta tanpa dikuasai oleh keinginan tertentu).Membuka diri yang dimaksud pada saat berinteraksi dengan air dalam proses melukat, adalah mengembangkan kesadaran pada lapisan ke empat dan kelima dari Pancamaya- kosha tersebut. Ini adalah proses recharge diri dengan energi alam yang bersifat murni. Menghasilkan recovery kondisi kesehatan dan keseimbangan pada semua lapisan kesadaran diri dan juga terciptanya keselarasan antar lapisan tersebut (lenyapnya konflik di dalam diri). Kondisi seperti itu memberi ruang berkembangnya rasa kasih, menggantikan dominasi ego dan segala hasrat yang bersumber dari pikiran, yang selama ini hanya menghasilkan kekacauan, masalah, konflik dan penderitaan.

Hasil penelitian Dr. Masaru Emoto dari Jepang yang sangat terkenal, menunjukkan bahwa air sangat sensitif dapat merespon apapun yang ada di sekitarnya. Apabila air diperlakukan dengan kasar atau apabila di dekat air tersebut terjadi kondisi yang kotor, jorok, atau perilaku kasar, maka molekul air secara cepat akan merespon dengan membentuk formasi yang tidak beraturan. 
Sementara sebaliknya, bila perlakuan terhadap air bersifat positif dan mulia, atau di sekitar air tersebut terjadi perilaku penuh kemuliaan, maka molekul air berubah menjadi Kristal-kristal yang indah. Karena badan manusia terdiri dari $70 \%$ sampai dengan $90 \%$ adalah unsur air, maka penemuan ini membuktikan bahwa air di dalam tubuh manusia bereaksi terhadap stimuli dari lingkungan. Keadaan lingkungan dan perlakuan yang diterima seseorang, akan mempengaruhi dan menentukan keadaan, keseimbangan, kesehatan dan kesadaran orang tersebut.

Fenomena 'aneh' yang terjadi di Penglukatan Sebatu bisa jadi merupakan reaksi yang timbul akibat interaksi antara air dan badan dalam intensitas yang sangat tinggi. Melalui media air yang berkualitas terbaik, proses melukat dapat memberikan treatment yang sangat baik dalam konteks pemberdayaan diri secara holistik.

Dalam ilmu Ayurveda, juga dijelaskan lima unsur pembentuk badan manusia yang sangat menentukan sifat dari seseorang. Tiga yang paling dominan yang harus seimbang adalah unsur Angin (Bayu), Api (Teja) dan Air (Apah). Kelebihan unsur api, membuat seseorang akan bersifat temperamental. Kelebihan angin menjadi tidak tetap pendirian atau 'angin-anginan' dan tidak mampu fokus. Kelebihan unsur air, seseorang menjadi pemalas dan tidak bisa sigap. Untuk menyeimbangkan ketiga unsur tersebut di dalam diri, agar menghasilkan pribadi yang simbang dan sigap, proses melukat sangat direkomendasi bagi orang-orang yang kelebihan unsur api dan angin.

Wisatawan merupakan seseorang yang berpergian jauh dari tempat tinggalnya selama waktu tertentu untuk mencari pengalaman dengan interaksi dari kegiatan dan atau karakteristik lingkungan tempat dimana wisatawan mengunjunginya. Wisatawan memiliki berbagai faktor pendorong (push factors) yang menyebabkan wisatawan memutuskan untuk melakukan perjalanan yang biasanya muncul dari dalam diri manusia dengan tujuan memuaskan kebutuhan psikologinya, seperti tujuan refreshing, sekedar untuk memalingkan perhatian kepada hal-hal lain di luar kesibukan dan rutinitasnya. Dalam teori pemuasan kebutuhan (content theory) yang dijelaskan oleh Abraham Maslow, ada lima kebutuhan manusia, dan wisatawan berada pada self-esteem karena tiga kebutuhan dasar lainnya sudah terpenuhi. Sebagian wisatawan yang lain memiliki tujuan yang lebih mendalam, yaitu mencari pengalaman baru atau sesuatu yang baru yang lebih bermakna di dalam hidupnya yakni aktualisasi diri (tingkatan tertinggi dalam teori kebutuhan Maslow) yang menggunakan semua bakat, potensi, serta kualitas dan kapasitas secara penuh untuk kebutuhan individu wisatawan.

Dunia industri pariwisata sebagian besar menangkap segmen wisatawan yang yang menganggap berwisata itu adalah refreshing, yang menikmati sensasi dari ritual dalam atraksi wisata. Itu adalah segmen pasar yang lebih besar dan terlihat lebih menguntungkan secara finansial. "Banyak pihak yang ketakutan kehilangan ritual sehingga pelestarian ritual dan penciptaan ritual-ritual baru yang lebih menakjubkan perlu diupayakan untuk konsumsi pariwisata " (Donder, Craddha Edisi 79: Hal 39). Pariwisata model ini yang menghasilkan eksploitasi budaya dan agama, tanpa mampu membedakan mana wilayah profan atau komersial, dan mana yang menjadi wilayah yang sakral. Di sisi lain, jenis wisata seperti ini menimbulkan ketergantungan masyarakat terhadap pariwisata. 
Walaupun ritual melukat memiliki begitu banyak sensasi menarik di dalamnya, esensinya sebagai kegiatan pemberdayaan diri sebagaimana diuraikan sebelumnya, dan didukung dengan penjelasan secara kreatif logis dan berbasis metode ilmiah, akan menjadi perspektif baru pariwisata spiritual. Dalam wawancara dengan beberapa wisatawan asing yang mengikuti kegiatan spiritual di Ubud, mereka memang merasakan sesuatu yang baru melalui pengalamanpengalaman langsung yang selama ini tidak mereka temukan di negara mereka.Kalau dihubungkan dengan data peningkatan kunjungan wisatawan asing ke Penglukatan Pura Dalem Pingit dan Pura Kusti di Desa Pekraman Sebatu Tegallalang Gianyar, maka tujuan untuk mendapatkan pengalaman baru tersebut sangat relevan. Inilah daya tarik wisata spiritual, yang membedakannya dengan daya tarik wisata konvensional yang berbasis materi dan sensasi.

Masyarakat Bali harus percaya diri dan kreatif melakukan perubahan-perubahan, baik dalam hal sikap, maupun hal-hal yang menyangkut teknis pengelolaan pariwisata. Kembalikan pemahaman bahwa dunia pariwisata ada karena Bali memiliki keunikan budaya yang memberikan manfaat bagi wisatawan. Dalam pariwisata spiritual, bukan Bali yang 'menjual' dirinya, melainkan wisatawan yang karena ketertarikan dan kebutuhannya, datang untuk memberikan apresiasi dengan 'membeli' Bali. Mereka 'membeli' Bali karena mencintai dan mengagumi Bali, dan berusaha menjadi bagian dari kehidupan budaya Bali selama mereka di sini.

Dengan pemahaman dan kepercayaan diri seperti ini, sebenarnya tidak perlu ada rekayasa obyek wisata di Bali, atau dibangunnya sebuah obyek wisata hanya berupa simulasi budaya buatan. Objek wisata di Bali sendiri masih banyak yang dapat digali, yang benar-benar dapat memberdayakan masyarakat.

Sebagaimana fenomena ritual melukat di Penglukatan Pura Dalem Pingit dan Pura Kusti di Desa Pekraman Sebatu Tegallalang Gianyar,pertama-tama yang terpenting adalah bagaimana masyarakat lokal menjadikan ritual melukat ini sebagai kegiatan yang benar-benar bermakna dan efektif untuk memberdayakan diri. Ketika ritual yang menjadi bagian dari budaya dan kearifan lokal menjadi kuat mengakar pada masyarakatnya sendiri, maka ritual tersebut menjadi layak untuk dinikmati juga oleh wisatawan. Inilah konsep wisata spiritual dan kekuatannya. Adanya manfaat positif akan menarik wisatwan untuk melibatkan diri dalam keseluruhan rangkaian prosesi melukat.

Kondisi pengelolaan obyek wisata secara umum selama ini, di Bali khususnya, memiliki permasalahan-permasalahan sebagaimana akan diuraikan berikut. Dalam setiap uraian diberikan analisis antidotnya masing-masing, sebagai sebuah pemikiran solusi.

1. Tidak ada ketertarikan khusus yang membuat kedatangan wisatawan berulangulang ke sebuah obyek wisata yang sama, karena pengalaman dan pengetahuan yang diperolehnya tidak meluas. Wisatawan cenderung hanya sekali visit untuk sekedar 'melihat' objek wisata yang dikunjunginya.Wisata spiritual melukat berfungsirecharge energy dan pemberdayaan diri secara holistik. Kekuatannya terletak pada sifatnya yang memang repetitiveness atau berulang-ulang. Wisatawan akan hadir berkelanjutan dengan hasil peningkatan kualitas kesadaran, kedamaian, kesehatan dan kebahagiaan; 
2. Kurangnya penjelasan yang bersifat ilmiah dan logis, atau cenderung menggunakan 'bahasa seadanya' sebagaimana dipergunakan dalam keseharian masyarakat lokal (Gaya penyampaian dan titik tekan setiap hal seharusnya mengikuti perspektif wisatawan). Dari segi konten, hanya mengandalkan keunikan yang bernuansa 'klenik', sekedar unik atau tidak lazim.Penjelasan yang diberikan dalam tulisan ini dapat menjadi acuan. Segala sesuatu yang mengandalkan kesadaran dan pemberdayaan diri, akan jauh dari kesan klenik;

3. Wisatawan hanya disuguhi atraksi budaya, tidak sampai dibuat mengaguminya. Latar belakang, esensi dan tujuan setiap atraksi / ritual / budaya, tidak disampaikan secara mendalam dan menggugah. Wisatawan menjadi sebatas merasa heran masih ada kegiatan-kegiatan seperti ini di jaman sekarang. Akhirnya banyak diantara mereka tidak menunjukkan sikap menghargai, bahkan cenderung bersikap melecehkan. Mereka menjadi merasa lebih hebat, sekaligus merasa kali ini berada pada posisi dibutuhkan kemampuan dekodifikasi atau mengurai nilai-nilai tinggi dari kearifan lokal yang selama ini tersembunyi di balik sensasi, mampu menumbuhkan kebanggaan sekaligus rasa percaya diri. Merekalah yang membutuhkan wisata spiritual yang sarat dengan nilai pemberdayaan diri yang memberikan mereka pengalaman baru tentang kehidupan;

4. Memposisikan wisatawan hanya sebagai penonton, tidak banyak dilibatkan dalam setiap atraksi budaya (kalau pun ada, hanya sekedar demonstrasi singkat). Mereka tidak mendapatkan pengalaman baru yang betul-betul berkesan dan membuat mereka memiliki cara pandang baru. Wisata spiritual melukat memberikan pengalaman berbeda, berkesan dan membekas kuat di hati wisatawan. Dengan demikian, mereka akan bercerita kepada kawan / kerabat dengan penuh semangat atas penemuan batinnya. Dalam dunia pemasaran, word of mouth seperti ini merupakan metode yang sangat ampuh dan efektif dalam memperkenalkan dan memasarkan destinasi atau objek wisata.

5. Indikasi yang dapat ditangkap melalui sikap masyarakat industri pariwisata terhadap wisatawan asing (hal ini dapat dijadikan objek penelitian tersendiri), adalah bahwa mereka dipandang sebagai komoditi belaka, bukan sebagai manusia yang sama yang harus dilayani secara tulus. Menurut Informan, sebagian masyarakat Sebatu masih memiliki keraguan untuk mengkomersialkan tempat yang sangat mereka sucikan ini. Hal ini adalah indikasi bahwa masyarakat di Desa Pekraman Sebatu tidak materialistik. Sebuah kekuatan sikap yang sangat mendukung pengembangan wisata spiritual. Meningkatnya kunjungan wisatawan selama ini murni tanpa upaya pemasaran, tanpa mempropagandakan testemoni, walaupun bukti dan testimoni keberhasilanmasyarakat dan wisatawan yang melukat sudah ada dan banyak. Bagi mereka propaganda adalah janji. Siapa yang bisa memastikan dan menjanjikan sebuah kesembuhan ? Ini juga cerminan dari sikap yang tidak takabur dan rendah hati. Inilah spiritualitas secara kolektif.

\section{Simpulan}

1). Penglukatan Pura Dalem Pingit dan Pura Kusti Desa Pekraman Sebatu Tegallalang yang dibuka dengan Upakara Mendak Tirta tanggal 14 Nopember 
2007, merupakan tempat penglukatan yang diyakini secara Hindu diberkahi oleh Ida Batari Uma dan Ida Dewi Gangga, dengan kawigunan (manfaat utama) untuk menghilangkan segala kekotoran diri lahir dan batin, termasuk membersihkan diri dari penyakit non medis, serta tempat untuk memohon Sentana (keturunan). Sejak awal, tempat penglukatan ini sudah sangat diminati umat karena sensasi yang ada dan ditambah dengan semakin banyak pihak yang merasakan manfaatnya.Keyakinan seperti ini akan terus berkembang secara horizontal meluas sebagai sebuah fenomena beragama secara eksoteris. Pada tingkatan ini, melukat merupakan obyek wisata dengan daya tarik ritual yang berbasis sensasi.

2). Melukat dapat dirasionalisasi sebagai sebuah bentuk pemberdayaan diri secara holistik menyangkut pembersihan dan pemberdayaan kelima lapisan kesadaran dalam diri, yaitu

1. Annamayakosha (Badan fisik),

2. Pranamayakosha (Energi/nafas),

3. Manomayakosha (Mind/Mental-emotional)

4. Vjnanamayakosha (Buddhi/Intuisi)

5. Anandamayakosha (Kesadaran Murni)

Air terbukti secara ilmiah memang memiliki karakteristik yang ideal sebagai media pemberdayaan diri. Melukat dengan media air memberikan treatment yang sangat signifikan terhadap unsur air (apah) di dalam diri, sehingga tercipta keseimbangan dan formulasi ideal yang selaras antar lapisan kesadaran di dalam diri. Kesehatan dan kebugaran akan menjadi bonus dengan sendirinya.

Memaknai esensi melukat dan melakoni prosesinya secara meditatif sebagai bentuk pemberdayaan diri, adalah bentuk perubahan pemahaman dan kesadaran, dari ritual menjadi spiritual. Hal ini merupakan progres kemajuan rohani dari penganut keagamaan eksoteris menuju isoteris, dari kesadaran kulit menuju kesadaran isi.

3). Pertama-tama, masyarakat Bali harus mampu menjadikan ritual melukat sebagai gerakan spiritualitas atau pemberdayaan diri yang membawa manfaat besar bagi kemajuan kehidupan masyarakat, setelah itu ritual melukat ini sangat layak dijadikan daya tarik wisata spiritual, tidak berhenti sebatas wisata ritual yang berorientasi sensasi.

Tanpa harus sengaja melakukan propaganda, apalagi rekayasa promosi, pengalaman langsung yang penuh kesan yang dialami wisatawan di dalam menjalankan prosesi melukat setelah mendapatkan pemahaman esensi melukat secara spiritual, akan menghasilkan testimoni yang kuat dari mulut ke mulut .The power words of mouth inidengan sendirinya akan menjadi kekuatan propaganda yang dahsyatdalam pemasaran.

Untuk itu, yangperlu dikembangkan adalah kemampuan untuk menjelaskan esensi ritual melukat dengan cara yang logis, ilmiah, sekaligus menarik, dari perspektif wisatawan. Wisatawan asing sangat tidak tertarik sesuatu yang berbau klenik. Esensi tersebut adalah hasil dekodifikasi nilai-nilai kearifan lokal yang tersembunyi di dalam tradisi ritual melukat. 


\section{Daftar Pustaka}

Anand Krishna, Memaknai Seruan Ajeg Bali, Majalah Craddha Edisi ke-82, Tahun XVIII, Mei-Juni 2018 Halaman 33-34;

Donder, Evolusi Pemahaman dari Ritual ke Spiritual,Majalah Craddha Edisi ke-79, Tahun XVII, Nopember - Desember 2017 Halaman 36-39;

Engkus Kuswarno, 2009, Metodologi Penelitian Komunikasi FENOMENOLOGI Konsepsi, Pedoman, dan Contoh Penelitiannya, Bandung, Widya Padjadjaran;

Feist, Jess , 2010, Teori Kepribadian : Theories of Personality. Salemba Humanika;

IB Dharmika, 2017, Peradaban Air, Denpasar, Sakha Press;

Kusumaningrum, Dian. 2009. Persepsi Wisatawan Nusantara Terhadap Daya Tarik Wisata di Kota Palembang. Tesis PS. Magister Kajian Pariwisata. Univ. Gadjah Mada;

Mahardika, Komunikasi Meditatif dalam Konsepsi Hindu Sebagai Solusi bagi Kemerosotan Spiritualitas Masyarakat Modern, Prosiding Seminar Nasional Komunikasi Fakultas Dharma Duta IHDN Denpasar, 22 Mei 2018;

Swami Sarvanand, 1921, Taittiriya Upanishad II Brahmananda Valli Chapter II-IV; Madras, Thomson \& Co;

Triwidodo, Nina, Gede, Krishna, 2005, Mengungkap Misteri Air Mengubah Dunia dengan Kesadaran Baru, Jakarta, PT. One Earth Media. 